\title{
Serum Ascites Albumin Gradient with Reference to Ascites in Cirrhosis with Portal Hypertenson
}

\author{
Dr.S.Selvamani.Md ${ }^{1}$, Dr.Shiny Thomas ${ }^{2}$, \\ ${ }^{1}$ Associate Professor, Department Of General Medicine, Chengalpet Medical College \& Hospital. \\ Chengalpattu \\ ${ }^{3}$ Junior Resident In General Medicine, Department Of General Medicine, Chengalpet Medical College \& \\ Hospital, Chengalpattu
}

\begin{abstract}
Ascites is one of the most common presentation in patient with liver diseases, especially in patients with cirrhosis of liver .Alcohol is one of the most common cause for the cirrhosis of liver. Serum ascites albumin gradient is very useful in differentiating the cause of ascites is due to portal hypertension or not. SAAG is one of the easy method to find out whether the ascites is due to portal hypertension or not by simply doing ascitic fluid analysis. Aim of the study: to study about the correlation between SAAG and the gradient of ascites and its change with diuretic therapy and its relation with ascitic fluid total protein.

Methods and study: newly diagnosed patients with ascites, who was not on diuretic therapy were selected . ascitic fluid analysis were send along with serum albumin. SAAG value had been calculated and its relation with all aspects were studied. SAAG had been calculated before and after diuretic therapy and studied. Result: most of the patient came under high gradient as cites and had persistant high gradient even after diuretic therapy. Diuretic therapy did not produce any significant change in SAAG in the study population. The effect of diuretic therapy on Ascitic Fluid Total Protein had been studied and showed its not a good indicator of cirrhotic ascites especially after diuretic therapy.
\end{abstract}

\section{Introduction}

Cirrhosis of liver is one of the most common disease in our city. The most common cause for the cirrhosis is alcohol. Ascites is the most common presentation of the patients with cirrhosis . ascites is fluid collection in the peritoneal cavity because of disease in the liver,kidney and heart and some other rare causes also there. Ascites is due to hypoproteinemia because of protein loss due to some disease involving liver and kidney. Portal hypertension due to cirrhosis of liver is one of the most common cause for ascites. From the analysis of ascitic fluid by its biochemical analysis, cell count, cytology, differential count, Gram stain and culture and sensitivity, various causes of ascites can be identified. One of the most important is calculating serum ascites albumin gradient, by SAAG value we can differentiate whether ascites this due to portal hypertension or not. Here in our study SAAG value is analysed in various aspect with respect to change with diuretic therapy,whether the diuretic therapy affects the Ascitic Fluid Total Protein (AFTP). Whether the cause of ascites is due to portal hypertension by using SAAG value.whether the patient having high or low gradiant ascites, which is most common all have been studied in the following study. The study conducted in the Chengalpet Medical College and Hospital, Chengalpettu, Tamil nadu.

\section{Aim Of The Study}

1.To to calculate serum ascites albumin gradient in various cases of cirrhotic ascites.

2.To check whether cirrhotics with ascites always had a high gradient ascites without exception.

3.If there is exception to find out the percentage of it

4.To find out the effect of diuretic therapy on ascitic fluid total protein(AFTP) in cirrhotic ascites.

5.To fine out the effect of diuretic therapy on serum ascites albumin gradient in cirrhotic ascites.

\section{Selection of patients:}

This study was conducted in Chengalpet Medical College and Hospital,Chengalpettu between January 2017 to April 2017. Patients with cirrhosis and ascites admitted in Medicine wards were selected and included in the study.

\section{Inclusion criteria:}

The patients selected are newly detected ascites patients who were not given any diuretic therapy previously. 


\section{Exclusion criteria:}

The patients with ascites who is already on diuretic therapy.

Those who didn't give consent.

\section{Methodology}

Serum and ascitic fluid were collected simultaneously (maximum interval of 5 minutes) and personally handed over to the laboratory. They were tested for albumin and total protein concentration in both serum and ascitic fluid,manual cell count, differential count, malignant cells, cultures and smear study for both acid fast and Grams stain. Biuret test was used for the estimation of total protein and albumin by the bromocresol green (BCG) dye method in semiautomated analyser. SAAG was calculated. Portal hypertension was diagnosed with clinical features of splenomegaly, collateral blood vessels and caput medusa if present. In the study population esophageal varices seen in OGD scopy were taken as indirect evidence of portal hypertension. USG abdomen was done for all patients and the coarse heterogenous echotexture of liver was taken as direct evidence of cirrhosis. Splenomegaly and portal vein diameter more than $1.3 \mathrm{~cm}$ was taken as indirect evidence of portal hypertension. All the patients were given Tab.Frusemide $40 \mathrm{mg}$ OD and Tab. Spironolactone $100 \mathrm{mg}$ OD for 7 days. Response to therapy was identified clinically by daily measurement of urine output,body weight and abdominal girth. Repeat serum and ascitic fluid albumin analysis were done after 7 days and gradient determined again.

\section{Results And Data Analysis}

The serum ascites albumin gradient (SAAG) was determined in all cases of cirrhotic ascites.

Out of 60 patients , 31 were females and 29 were males.

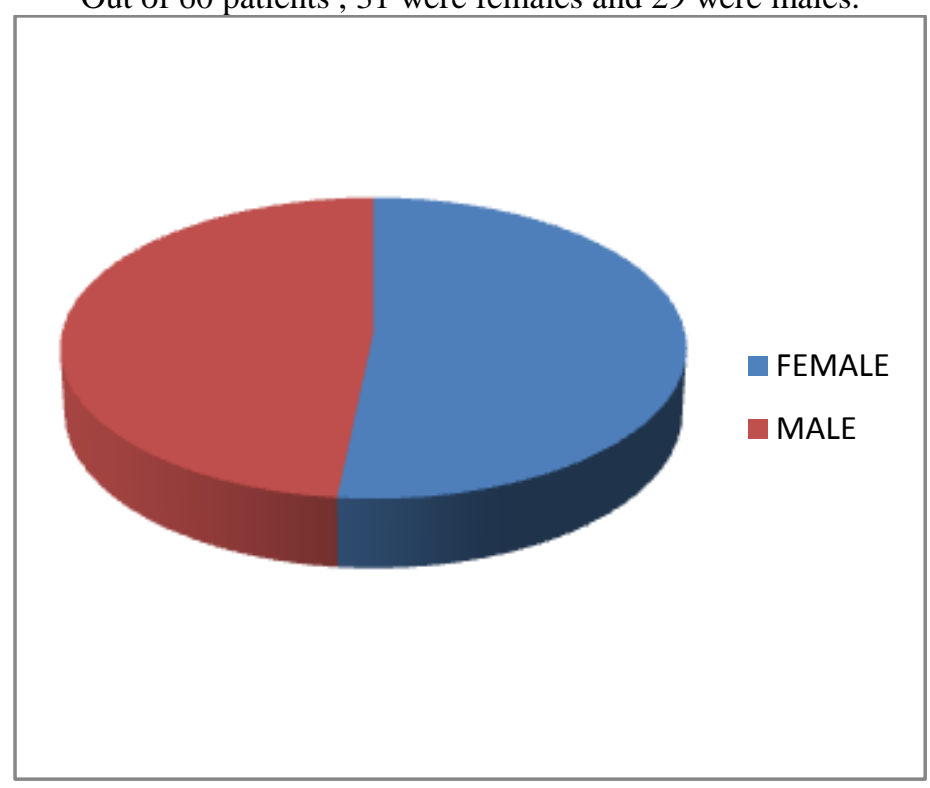

Age Distribution

\begin{tabular}{|l|l|l|}
\hline Age Group & Number of Patients & Percentage \\
\hline $10-20$ & 1 & $1.6 \%$ \\
\hline $21-30$ & 2 & $3.2 \%$ \\
\hline $31-40$ & 13 & $21.66 \%$ \\
\hline $41-50$ & 20 & $33.33 \%$ \\
\hline $51-60$ & 19 & $31.66 \%$ \\
\hline $61-70$ & 4 & $6.66 \%$ \\
\hline$>70$ & 1 & $1.6 \%$ \\
\hline
\end{tabular}

52 out of 60 patients $(86.67 \%)$ were between 30 and 60 years. Only 1 patient $(1.6 \%)$ was below 20 years , 2 patients $(3.2 \%)$ were between $21-30,13$ patients $(21.66 \%)$ were between $31-40.20$ patients $(33.33 \%)$ were between $41-50,19$ patients $(31.66 \%)$ were between $51-60,4$ patients $(6.66 \%)$ were between $61-70$ and 1 patient $(1.6 \%)$ was more than 70 years of age. 


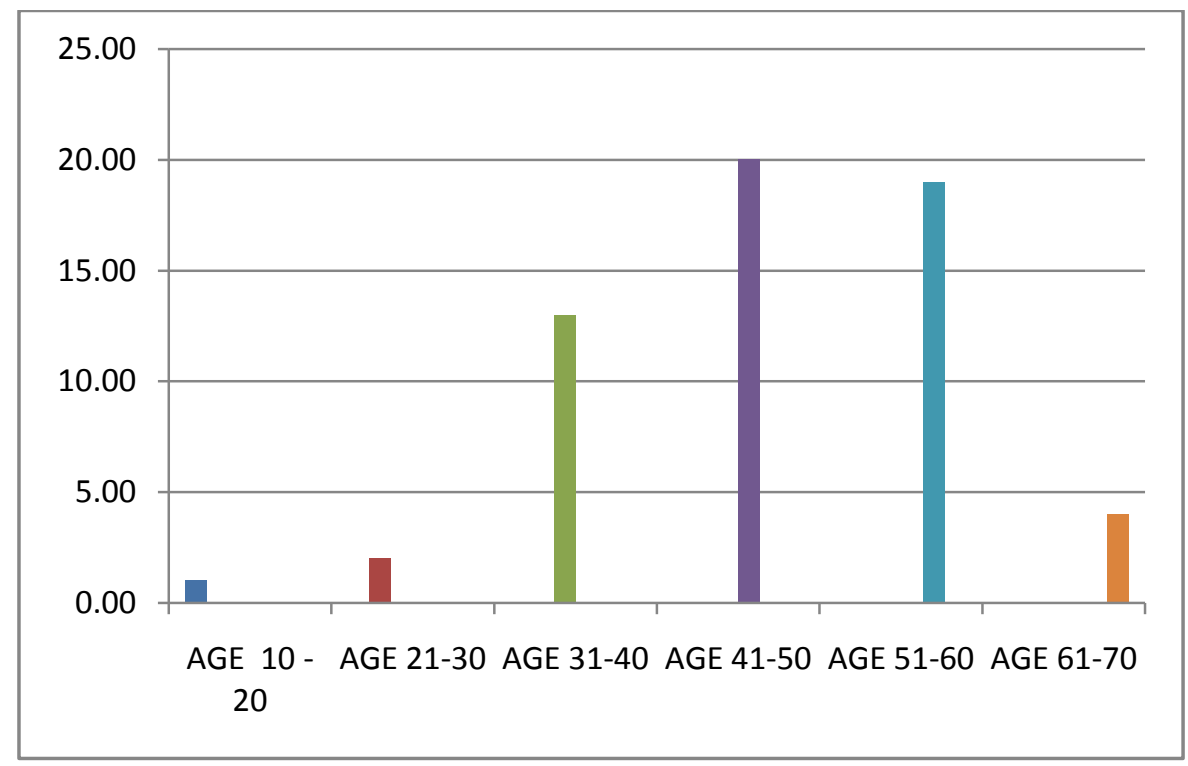

\begin{tabular}{|c|c|c|}
\hline \multicolumn{3}{|c|}{ Oesophageal Varices On Ogd Scopy } \\
\hline Grade & Number of patients & Percentage \\
\hline I & 12 & 20 \\
\hline II & 34 & 56.66 \\
\hline III & 14 & 23.33 \\
\hline IV & 0 & 0 \\
\hline
\end{tabular}

OGD scopy was done for all sixty patients. Oesophageal varices were observed. Out of 60 patients 12 patients (20\%) showed grade I varices, 34 patients $(56.66 \%)$ showed grade II varices , 14 patients $(23.33 \%)$ showed grade III varices, and none showed grade IV varices.

Usg Abdomen
\begin{tabular}{|l|l|l|}
\hline USG Abdomen & Number of Patients & Percentage \\
\hline With Hepatosplenomegaly & 12 & 20 \\
\hline With Hepatomegaly & 11 & 18.33 \\
\hline With splenomegaly & 37 & 61.66 \\
\hline
\end{tabular}

USG abdomen was done for all the sixty patients . 12 patients (20\%) had hepatosplenomegaly, 11 patients $(18.33 \%)$ had hepatomegaly alone and 37 patients $(61.66 \%)$ had splenomegaly with contracted liver. All the 60 patients had ascites. Out of the 60 patients , $56(93.34 \%)$ had SAAG more than $1.1 \mathrm{~g} / \mathrm{dl}$ and hence came under high gradient ascites. This is concordant with Runyon series when there was $96.7 \%$ accuracy in categorising a cirrhotic ascites as high gradient. During treatment the urine output increased and body weight and abdominal girth decreased. Patients were observed for 1 week.

\begin{tabular}{|l|l|l|}
\multicolumn{3}{l}{ Decrease In Body Weight } \\
\begin{tabular}{|l|l|l|}
\hline Body weight & Number of patients & Percentage \\
\hline$<3 \mathrm{~kg}$ & 12 & 20 \\
\hline $3-7 \mathrm{~kg}$ & 48 & 80 \\
\hline $.7 \mathrm{~kg}$ & 0 & 0 \\
\hline
\end{tabular}
\end{tabular}

Out of 60 patients, 12 patients (20\%) showed a decrease in body weight of $<3 \mathrm{~kg}$, 48 patients $(80 \%)$ showed a decreased in body weight of 3-7 kg and none showed a body weight fall more than $7 \mathrm{~kg}$

Decrease In Abdominal Circumference

\begin{tabular}{|l|l|l|}
\hline Abdominal circumference & Number of patients & Percentage \\
\hline$<3 \mathrm{~cm}$ & 11 & 18.33 \\
\hline $3-7 \mathrm{~cm}$ & 49 & 82.66 \\
\hline$>7 \mathrm{~cm}$ & 0 & 0 \\
\hline
\end{tabular}

Out of 60 patients, 11 patients $(18.33 \%)$ showed a decrease in abdominal circumference of $<3 \mathrm{~cm}, 49$ patients $(81.66 \%)$ showed a decrease in abdominal circumference of 3-7 cm and none $\mathrm{s}$ howed a decrease in abdominal circumference of $>7 \mathrm{~cm}$. 
None of the patients had jaundice, hematemesis, malena, hydrothorax, hepatorenal syndrome or hepatic encephalopathy at the time of initiation of therapy or during treatment. 56 out of 56 patients had high gradient ascites even after diuretic therapy. This is concordant with Runyon series where he derived that diuretic therapy did not change a high gradient ascites.

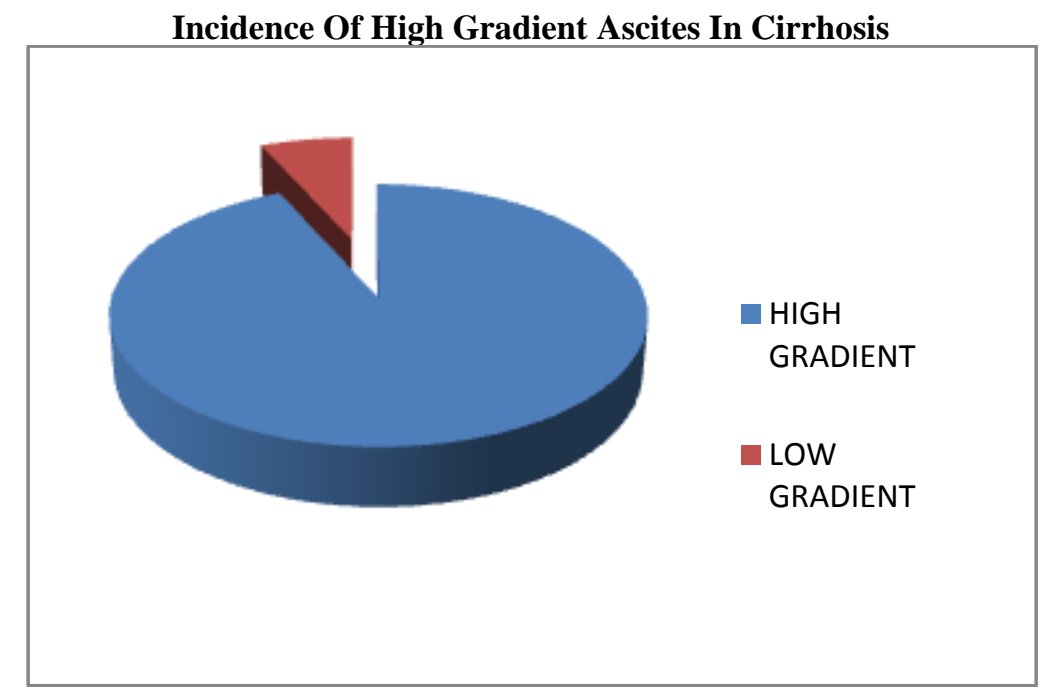

The effect of diuretic therapy on Ascitic Fluid Total Protein (AFTP) was studied. The mean AFTP before diuretic therapy was $1.621 \mathrm{gm} / \mathrm{dl}$. After diuretic therapy the mean ascitic fluid total protein (AFTP) increased to $2.623 \mathrm{gm} / \mathrm{dl}$. This is in comparison with the studies by Runyon where AFTP values were 1.44 and $2.33 \mathrm{gm} / \mathrm{dl}$ before and after diuretic therapy.

Diuretic therapy did not produce any significant change in SAAG in the study population. Even though there was an increase in ascitic fluid albumin concentration there was a proportionate increase in serum albumin concentration and hence no change. The average SAAG values in the study population before and after dieresis were $1.6433 \mathrm{gm} / \mathrm{dl}$ and $1.633 \mathrm{gm} / \mathrm{dl}$ respectively. This is in comparison with $1.81 \mathrm{gm} / \mathrm{dl}$ and $1.83 \mathrm{gm} / \mathrm{dl} \mathrm{of}$ Runyon series.

\section{Conclusion}

The serum ascites albumin gradient was determined in all cases of cirrhotic ascites.

Out of 60 patients 31 were females and 29 were males.52 out of 60 patients $(86.67 \%)$ were between 30 and 60 years.Out of the 60 patients 56 had SAAG,more than $1.1 \mathrm{~g} / \mathrm{dL}$ and hence came under high gradient ascites constituting a percentage of 93.34 All the 56 patients had high gradient ascites even after diuretic therapy. The effect of diuretic therapy on Ascitic Fluid Total Protein (AFTP) was studied. The mean AFTP before diuretic therapy was $1.621 \mathrm{~g} / \mathrm{dl}$. After diuretic therapy the AFTP increased to $2.623 \mathrm{~g} / \mathrm{dl}$. Diuretic therapy did not produce any significant change in SAAG I the study population. Even though there was an increase in asciticfluid albumin concentration there was a proportionate increase in serum albumin concentration and hence no change. The average SAAG values in the study population before and after diuresis were 1.6433 $\mathrm{g} / \mathrm{dl}$ and $1.633 \mathrm{~g} / \mathrm{dl}$ respectively. herefore AFTP is not a good indicator of cirrhotic ascites especially after diuretic therapy Response to diuretic therapy in cirrhotic ascites using combination of diuretics is stated to be about $90 \%$ with about $10 \%$ becoming refractory. In the study population all the patients responded to diuretic therapy.

\section{References}

[1]. Albillos A, Cuervas-Mons V, Millan I et al. Ascitic fluid polymorphonuclear cell count and serum to ascites albumin gradient in the diagnosis of bacterial peritonitis. Gastroenterology 1990;98:134

[2]. Andrea M, Sola R ,Sitgdes-Serra A et al. Risk factors for spontaneous bacterial peritoni, in cirrhotic patients with ascites . Gastroenterology 1993;104:1133

[3]. Arroyo V, Jimenez W. Complications of cirrhosis. 11. Renal and circulatory dysfunction. Lights and shadows in an important clinical problem. J. Hepetol. 2000;32 (suppl. 1); 157

[4]. Arroyo V, Gines A, Sal6J. A European survey on the treatment of ascites in cirrhosis. J. Hepatol. 1994;21:667.

[5]. Brensing KA, Textor J, Perz J et al. Long-term outcome after transjugular intrahepatic portosystemic shunt in non transplantcirrhotics with hepatorenal syndrome; a phaseII study .Gut 2000;47:288

[6]. Chang C-S, Chen G-H, Lien H-C et al. Small intestine dysmotility and bacterial overgrowth in cirrhotic patients with spontaneous bacterial peritonitis. Hepatology 1998;28: 1187. 
[7]. Fernandez-Esparrach G, Sanchez- Fueyo A, Gincs P et al. A prognostic model for predicting survival in cirrhosis with ascites J. Hepatol 2000;34.;46

[8]. Gadano A, Moreau R, Pessione F et al. Aguaretic effects of niravoline, a Kappa-opioid agonist, in patients with cirrhosis J. Hepatol 2000;32:38.

[9]. Garcia- T sao G. Current management of the complications of cirrhosis and portal hypertension ; varicealhaemorrhage, ascites, and spontaneous bacterial peritoninitis Gastroenterology 2001;120:726.

[10]. Gentilini P, Casini -RaggiV,DiPior, G et al.Albumin improves the response to diuretics in patients with cirrhosis and ascites results of a randomized,controlled trial J Hepatol 1999,30:639.

[11]. Gines P ,Arroyo V, Quintero E et al. Comparison of paracentesis and diuretics in the treatment of cirrhotics with tense ascites. Results of a randomized study. Gastroenterology 1987;93;234.

[12]. Gines P, Arroyo V, Vargas V et al. Paracentesis with intravenous infusion of albumin as compared with peritoneovenous shunting in cirrhosis with refractory ascites. N. Engl/ Med 1991;325;829

[13]. Gines P, Schrier RW. The arterial vasodilation hypothesis of ascites formation in cirrhosis .In Arroyo V, Gines P, Rodes J. Schrier RW, eds Ascites and renal dysfunction in Liver disease pathology,Diagnosis and treatment . Blackwell Science, Oxford, 1999,p. 4111 .

[14]. Girgrah N, Liu P, Collier J, Blendis L, Wong F. Haemodynamic, renal sodium handling, and neurohormonal effects of acute administration of low dose losartan, an andiotensin II receptor antagonist , in preascitic cirrhosis Gut 2000;46;114.

[15]. Guevara M, Gins P, Jimenez W et al. Increased adrenomedullin levels in cirrhosis ;relationship with haemodynamic abnormalities and vasoconstriction systems. Gastroenterology 1998;114;336

[16]. Gilberg V, Bilzer M, Gerbes AL. Long-term therapy and retreatment of hepatorenal syndrome type 1 with omnipressin and dopamine. Hepatology 1999;30:870

[17]. Lazaridis KN, Frank JVV, Kroeka MJ et al.Hepatichydrothornx; pathogenesis, diagnosis and management . AM J Med 1990:25;135.

[18]. Lebrec K, Giuily N, Hadengue A et al. Transjugular intrahepatic portosystemic shunts: comparison with paracentesis in patients with cirrhosis and refractory ascites; a randomized trial. J .Hepatol 1996;25:135

[19]. Llovet JM, Bartoli R, Planas R et al. Selective intestinal decontamination with norfloxacin reduces bacterial translocation in ascetic cirrhosis rats exposed to haemorrhagic shock. Hepatology 1996;23:781

[20]. Maminchoc M, Kamath PS, Gordon FD et al. A model to predict poor survival in patients undergoing transjugular intrahepatic portosystemic shunts. Hepatology 2000;37;864

[21]. Singh N, Gayowski T, Yu VL et al, Trimethoprimsulfamethazazole for prevention of spontaneous bacterial peritonitis in cirrhosis, a randomized trial. Ann . Intern. Med 1995;122:595.

[22]. Schrier, R W, Arroyo , V, Bernardi, M, et al. Peripheral arterial vasodilation hypothesis; A proposal lot-the initiation of renal sodium and water retention in cirrhosis. Hepatology NA 151,1988.

[23]. Sherlock,S, and, Shaldon S. The etiology and management of ascites in patients with hepatic cirrhosis; A review . Gut4;95,1963.

[24]. Lieberman,F L, Denison E. K, and Reynolds, T 13. The relationship of plasma volume, portal hypertension, ascites, and renal sodium retention in cirrhosis: The overflow theory of ascites formation .Ann .N. Y. Acad. Sci. 70;202,1971.

[25]. Sogni. P. Moreau, R. Gadano. A, et al. The role of nitric oxide in the hyperdynamic circulatory syndrome associated with portal hypertension. J. Hepatol 23;218;1302,1992.

[26]. Cattau EL. Jr, Benjamin Sb, Kiluff TE, et al. The accuracy of the physical examination in the diagnosis of suspected ascites.1982;247:1164-1166

[27]. Goldberg BB, Goodman GA, Clearfield HR. Evaluation of ascites by ultrasound Radiology 1970;96:15-22

[28]. Runyon BA. Paracentesis of ascitic fluid; a safe procedure.Arch Intern Med 1986;146:2259-2261.

[29]. Runyon BA, Hoefs JC, Morgan TR. Ascitic fluid analysis in malignancy-related ascites Hepatology 1988;8:11(14-11(19.

[30]. MauerK,Manzione NC, Usefulness of the scrum-ascites albumin gradient in separating transudative from exudative ascites: another look. Dig. Disc. Sci, 1988;33:1208-1212.

[31]. Bar-Meir S, Lerner E, Conn HO, Analysis of ascitic fluid cirrhosis, Dig. Disc Sci, 1979;24:136-144.

[32]. Runyon BA, Montana BA, Akriviadis EA et al. The serum ascites albumins gradient is superior to the exudative transudate concept in the diff. Diagnosis of ascites. Ann. Intern. Med.1992,177:1215-220.

[33]. Runyon BA, Care of patients with ascites, New England Journal of Medicine,1994,330-337. 